\title{
Sivas Yıldızeli Ilcçesi Tülü Dokumalarının Özellikleri
}

Zuhal TÜRKTAŞ*

Mehmet Fatih ÇAKMAKTEPE**

\section{ÖZET}

Sivas, orta Anadolu'da yer alan ve el dokumacllığının önemli örneklerinin üretildiği bir il olarak karşımıza çıkmaktadır. Sivas Yıldızeli ilçesi ise tülü dokumacılığının önemli merkezlerindendir. İlçe merkezinde geçmişten günümüze taşınan tülü dokumaları bulunmakla birlikte, bazı yeni üretimler de söz konusudur. Yıldızeli ilçesinde bulunan tülü dokumalarının teknik ve desen özellikleri, üretim biçimleri ve bugünkü durumunu kapsayan bu çalışma ile merkezdeki tülü dokumaları hakkında bilgi vermek amaçlanmaktadır.

Tülü dokuma tekniği ile üretilen ürünler dokumacılık sanatları içerisinde az bulunur olmasıyla önemli bir özelliğe sahiptir. İlçe merkezinde Kaymakamlığın hazırlamış olduğu Avrupa Birliği destekli bir proje ile kaybolmaya yüz tutmuş olan dokuma geleneğinin, yörede yeniden canlandırılması ve devam etmesi sağlanmıştır. Eski örneklerin ve bu örneklere bağlı kalınarak yapılan günümüz tülü dokumalarının yöresel özellikleri tespit edilerek literatüre kazandırılması amaçlanmıştır.

Araştırmada 1950-2010 yılları arasında dokunmuş olan örnekler incelenmiş olup, bu örnekler kompozisyon, renk, kullanılan malzeme vb. Özellikler bakımından değerlen-

Yrd. Doç. Dr., Selçuk Üniversitesi, Mesleki Eğitim Fakültesi, Selçuklu-Konya, e-posta: zbezirci@selcuk.edu.tr

** Cumhuriyet Üniversitesi, SMYO, Öğretim Elemanı - Selçuk Üniversitesi Sosyal Bilimler Enstitüsü, El Dokumaları ve Örgüleri Eğitimi Anabilim Dalı, Master Öğrencisi, e-posta: fatihcakmaktepe@hotmail.com)

\section{The Characteristic of} Sivas Yıldızeli TülüWeavings

dirilmiştir. Yörede bulunan tülü dokumaları birbirini tekrar eder biçimde benzerlik gösterdiğinden bu sınırlı çalışmada katalog, karakteristik özellik taşıyan tek bir örnekle temsil edilmiş ve 6 örnek incelenmiştir. Ayrıca tülü dokumalarının bugünkü üretim koşulları yerinde incelenip, ürünlerin pazarlanması konusunda bilgi verilmeye çalışılarak önerilerde bulunulacaktır.

Anahtar Kelimeler: Dokumacılık, El sanatları, Tülü üretimi, Tülü desenleri.

\section{ABSTRACT}

Sivas- a province in central Anatolia- emerges as a city where important samples of hand fabrics are produced. Yıldizeli county of Sivas province is one of the important centers for tülü fabrics. In the center of the town, besides tülü fabrics preserved from the past to present, new productions are available, as well. This study which covers technique and pattern characteristics, production styles and current state of tülü fabrics in Yıldızeli county, aims to give information about tülü fabrics.

As products produced with tülü fabric technique are rare among fabric arts, they are very special. Thanks to a European Union supported Project prepared by district governorship, almost extinct fabric tradition was revived in the region and continued in the center of the county. The main aim of the study is to determine the regional characteristics of old samples and recent tülü fabrics -in which traditional weaving techniques were observed- and to add them to the literature. 
In the study weavings produced between the years 1950-2010 were examined and these samples were assessed in terms of composition, color, materials used etc. The number of tülü fabrics was limited with 6 samples which vary in terms of date of production, technique, pattern and color properties. Besides, some suggestions will be made and information about the marketing of these fabrics will be given by examining the current production conditions of mat fabrics in their place.

Keywords: Weaving, Hand crafts, Tülü production, Tülü Patterns.

\section{Giriş}

Sivas coğrafi yapısı itibariyle günümüzde olduğu gibi tarihin tüm dönemlerinde de doğu-batı, kuzeygüney hatlarının ulaşım ağının kavşak noktasında bulunmasından jeopolitik ve stratejik öneme sahip olmuştur. Şehir bir bakıma Anadolu'nun ortasında bulunmasından dolayı Bizans ve Anadolu Selçukluları döneminde şehrin oldukça gelişip zaman, zaman siyasi başkent ve kültürel açıdan da bir ilim ve sanat merkezi olmasında bu ulaşımın ve stratejik konumunun büyük etkisi olmuştur.'

Sivas, orta Anadolu'da yer alan ve el dokumacilığının önemli örneklerinin üretildiği bir il olarak karşımıza çıkmaktadır. Sivas Yıldızeli ilçesi ise tülü dokumacılığının önemli merkezlerindendir.

Yıldızeli ilçe merkezinde ve çevresinde dokumacılık önemli bir geçim kaynağıdır. Dokunan halı ve kilimler, Şarkışla yöresinde dokunan halı ve kilimlerin özelliklerini taşır. Büyükağören ve Direkli nahiyesine bağlı Kızılırmak boyundaki köylerin tümünde halı ve kilim dokunmaktadır. Şarkışla-Yıldızeli sınırı arasındaki köylerde dokunan kilimlere motiflerinden dolayı "aynalı kilim" denir. Ayrıca Yıldızeli köylerinde "budaklı" adı verilen kilimler de dokunur. Davulalan ve Katıralan'ın halı heybeleri önemlidir. Kaman, Höyük, Sarıçal, Karakaya, Kale köyü, Yuvalı, Çayır ve Nallı köylerinde halı, halı yastık, makat halısı dokunmaktadır. 93 Muhacirlerinin oturduğu köylerde "Karslı kilimi" adı verilen kilimler dokunmaktadır. ${ }^{2}$

İlçe merkezinde geçmişten günümüze taşınan tülü dokumaları bulunmakla birlikte, bazı yeni üretimler de söz konusudur. Yıldızeli ilçesinde bulunan tülü dokumalarının teknik ve desen özellikleri, üretim biçimleri ve bugünkü durumunu kapsayan bu çalışma ile merkezdeki tülü dokumaları hakkında bilgi vermek amaçlanmaktadır

Tülü dokuma tekniği ile üretilen ürünler dokumacılık sanatları içerisinde az bulunur olmasıyla önem-

Sivas Ill Ylllı̆̆ı, Sivas Valiliği, Sivas, 2002, s. 31

2 K.Özen, Sivas Yöresi Geleneksel El Sanatları, İstanbul Kitabevi Yay1nevi, 2008, İstanbul, s. 120. li bir özelliğe sahiptir. İle merkezinde Kaymakamlğın hazırlamış olduğu Avrupa Birliği destekli bir proje ile kaybolmaya yüz tutmuş olan dokuma geleneğinin, yörede yeniden canlandırılması ve devam etmesi sağlanmıştır. Eski örneklerin ve bu örneklere bağ $l_{1}$ kalınarak yapılan günümüz tülü dokumalarının yöresel özellikleri tespit edilerek literatüre kazandırılması amaçlanmıştır.

Istar tip veya sarma tip metal tezgâhlarda dokunan, çözgü ve atkı iplikleri yün olan, ilme ipliği olarak yün ve çoğunlukla tiftik kullanılan, her ilme sırasından önce ve sonra 3 ile 30 sıra arasında düz dokuma tekniği (bezayağı) ile dokunan, havların uçları kesilmeden olduğu gibi bırakılan, yumuşak, kaba dokulu havlı dokumalara tülü denir. ${ }^{3}$

İnsanların yün ipliklerini çözgülerin bir üstünden bir altından geçirerek ilk önce kilim dokudukları, sonradan bu ipliklerin arasına yün ipliklerini düğümleyip kısa keserek halıyı buldukları sanılmaktadır. İnsanların önceleri çözgü ipliklerine uçları dışarı sarkan renkli yün ve tiftikleri düğümleyerek hayvan postunu taklit ettikleri ve giderek bunlardan asıl halıları geliştirdikleri bilinmektedir. Bu yaygılara değişik yörelerde hopan, geve, tülü ve tülüce gibi adlar verilmektedir. ${ }^{4}$

Geve, Tülü, Tülüce, Filikli ve Hırsek gibi çeşitli adlarla bilinen suni post görünüşündeki bu dokumalar, aynen halı gibi dokunmuş ve ilmelerde Türk Düğümü kullanılmıştır. ${ }^{5}$

Halıda, eğrilmiş yün iplikleri, çözgü üzerine düğümlenerek elde edilir. Yapay postta, eğrilmemiş yün tutamları, halıda olduğu gibi, çözgü ipliklerinin üzerine düğüm yapılarak elde edilir. Teknik aynıdır, aradaki fark tüylü yüzeyi meydana getirecek malzemenin, birinde eğrilmiş yün ipi, ötekinde eğrilmemiş ham yün kullanılmasıdır.

Bu iki dokuma arasında, tüylü bir dokuma daha vardır ki, Buna Hopan denir. Bunda da, aynı biçimde düğüm tekniği kullanılır. Ancak, ilme ipi için, eğrilmiş fakat bükülmemiş yün ipi kullanılır. Yapay post görünüşündeki dokuma, Türkistan ve Anadolu'nun pek çok yerinde yapılmış ve günümüze kadar gelmiştir.

Bu üç dokumada görülen teknik özellik, önce yapay post görünüşündeki dokumanın yapıldığını, sonra gelişerek hopan elde edildiğini ve en sonunda halının ortaya çıktığını göstermektedir. Bu bakımdan yapay post görünüşündeki bu dokumaya halının anası denilebilmektedir.

Geve'nin Kars'tan Muğla'ya, Hakkari'den Kırklareli'ne kadar Anadolu'nun bütün yörelerinde

3 Megep, El Sanatları Teknolojisi, Tülü Dokuma, Mesleki Eğitim ve Öğretim Sisteminin Güçlendirilmesi Projesi, Milli Eğitim Bakanlığı, Ankara, 2008 s. 18.

4 Ç.Aytaç, Halı Deseni Tasarımı, Ostim Mesleki Eğitim Merkezi, Ankara, 2001, s.48.

5 N.Kırzıoğlu, Görgünay, Dügümlü Halının Öncüsü Geve/Tülü ve Benzeri Dokumalar, Türk Dünyası Araştırmaları Vakfı, İstanbul, 2000 s. 19. 
dokunduğunu ve bölgelere göre, Tülü, Tülüce, Filikli (tiftikten yapılanlara), Gebe, Gaba ve Hırsek gibi adlarla bilindiği kaynaklarda belirtilmektedir. Bu çalışmada Sivas tülü dokumalarının tülüce olarak isimlendirildiği tespit edilmiştir. ${ }^{6}$

Tülü dokumalarının sadece Anadolu'da değil, Azerbaycan, Yugoslavya, Moldavya, Bulgaristan, Yunanistan ve Türkmenistan'da da yapıldı̆̆ı tespit edilmiştir.

Tüylü dokumalarıyla ünlü merkezler Karapınar, Konya, Yükselen, Karaman, Taşkale ve Yahyalı'dır. Konya'nın tek renkli özellikle domates kırmızısı, koyu çilek kırmızısı, acı sarı tek renkli tülüleri, Taşkale'nin, Yahyalı'nın, Karaman ve Karapınar'ın çok renkli tülüleri vardır. Bazen yollu, bazen iç içe yerleştirilmiş mihrap nişleriyle bezenmiş Karapınar tülüleri dikkat çekmektedir. Bu arada Konya, Emirdağ, Sarayönü, Kulu, Cihanbeyli gibi merkezler kilim dokumaların ara, ara tülü dokuma bileşimleriyle uygulandığı örneklerle fark edilmektedir. Bileşik teknikle yünle uygulanmış bu örnekler arasında bir grup Kulu ve Cihanbeyli örneği, çözgüsünde beyaz pamuklu iplik kullanılması ile ayırt edilmektedir.?

\section{1. Tülü Dokumalarının Bugünkü Durumu}

Maliyetin düşük olması ve dokumanın kısa bir sürede tamamlanmasından dolayı halıya oranla tülü dokuması daha ekonomiktir. Ancak, Sivas halısı için oldukça yoğun bir talep vardır. Bu talepleri karşılamak amacıyla şu an yörede bulunan tüm tezgâhlarda Sivas halısı dokunmaktadır.

Yörede 2006-2007 yılları arasında, Yıldızeli Kaymakamlığı Sosyal Yardımlaşma ve Dayanışma Vakfı tarafından "Sivas Halısı ve Tarihi Tülüce Kilimi Mesleki Eğitim ve Pazarlama Projesi" adı altında AB desteği ile yürütülen bir proje hazırlanmıştır. Hazırlanan bu proje, bölgede yaşayan insanların gelirlerinin artırılması ve yaşam standartlarının geliştirilmesine katkı sağlamak amacıyla yapılmıştır.

Bu proje kapsamında yörede bir Eğitim Atölyesi oluşturulmuştur (Foto 13). Proje tamamlanmış olmasına rağmen, Eğitim Atölyesi'nde halen dokuma faaliyetleri devam etmektedir. Bu durum projenin amacına ulaşmış olduğunun bir göstergesidir.

Bu atölyede, pazarlama sonrası sağlanan kazanç, hammadde gideri düşüldükten sonra tamamen dokuyucuya kalmaktadır. Bu durum dokuma yapmak isteyenlerin atölyeyi tercih etmelerindeki büyük etkenlerden birisidir. Yaklaşık olarak 30Tl/ $\mathrm{m}^{2}$ tutarında

6 N. Kırzıoğlu, Görgünay, “Altaylarda Pazırık Kurganı'ndan Çıkan Motiflerin Anadolu ve Türk Cumhuriyetleri'nde Yaşayan İzlerinden Bazı Örnekler" Türk Soylu Halklarının Halı, Kilim, Cicim Sanatı Uluslararası Bilgi Şöleni Bildirileri, Atatürk Kültür Merkezi Başkanlığı Yayınları, Kayseri, 1996, s.137-150, s.138.

H.Ö.Barışta, "19-20. Yüzyıl İç Anadolu ve Orta Akdeniz Bölgesi Türk Kirkitli Dokumaları Üzerine" Türk Soylu Halklarının Hall, Kilim, Cicim Sanatı Uluslararası Bilgi Şöleni Bildirileri, Atatürk Kültür Merkezi Başkanlığı Yayınları, Kayseri, 1996, s. 39-56, s.46 hammadde kullanılarak üretilen tülünün satış fiyatı $140 \mathrm{Tl} . / \mathrm{m}^{2}$ 'dir. Sipariş usulü çalışıldı̆̆ından pazarlama sorunu bulunmamaktadır.

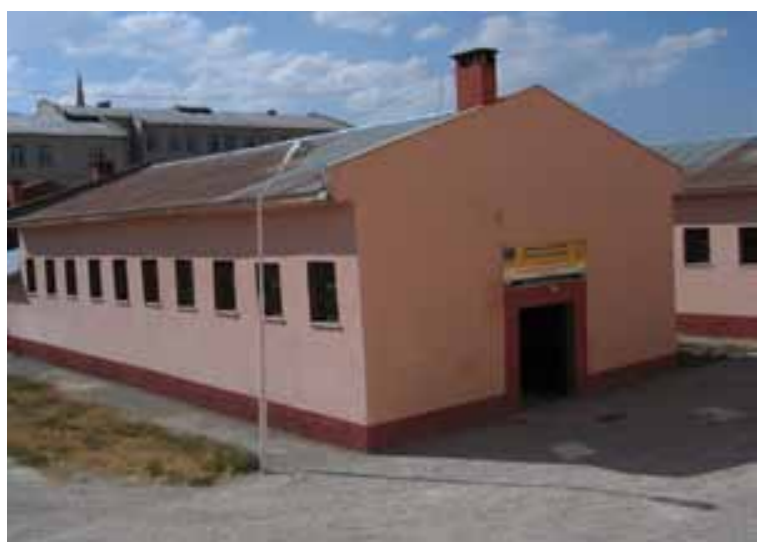

Foto 13. Eğitim atölyesi diş görünüşü.

\section{Materyal Yöntem}

Araştırmanın materyalini, Sivas Yıldızeli ilçe merkezinde dokunan ya da bugün Yıldızeli'nde bulunan dokumalar oluşturmaktadır. Yörede üretilen dokumalarda kullanılan araç ve gereçler yerinde incelenmiş, görsel olarak sunulmuştur. İncelenen örnekler, duvar örtüsü ve yer yaygısı olarak tespit edilmiştir. Ayrıca bu yörede, günümüzde tülü dokumasını devam ettirmek için çaba sarf eden, bu işe gönül vermiş insanlarla yapılan görüşmeler, atölyelerden ve kullanım yerlerinden çekilen görsel malzemeler de çalışmanın materyalini oluşturmaktadır.

Araştırma kapsamında incelenen her bir örnek için gözlem formu oluşturulmuş ve verilere ulaşılmıştır. Tülü dokumalarının; en, boy, filik uzunluğu, saçak uzunluğu, havlar arasındaki kilim dokuma

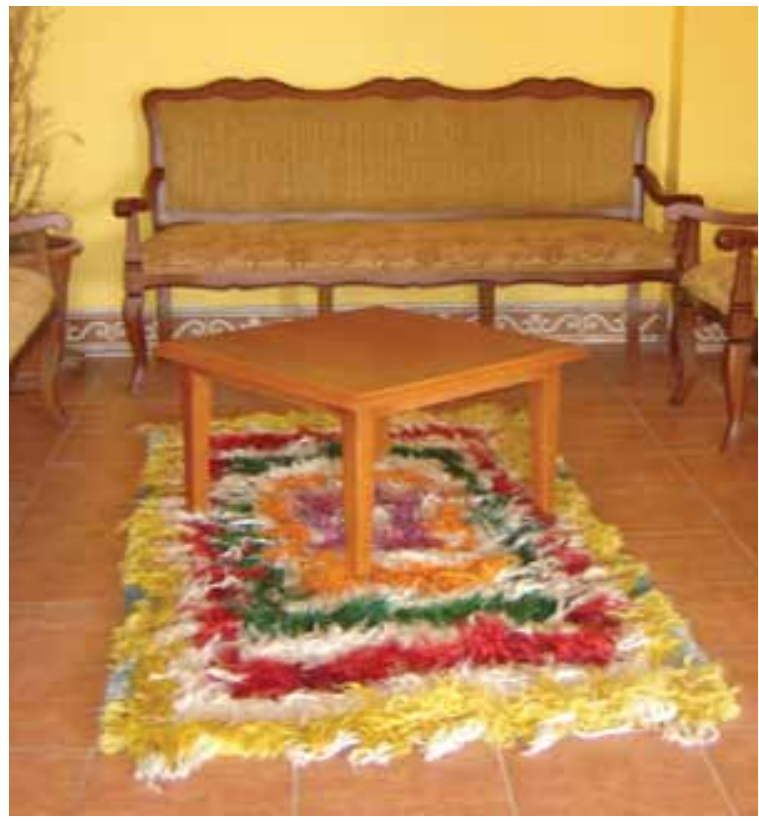

Foto 12. Tülünün dekor amaçlı kullanımı 


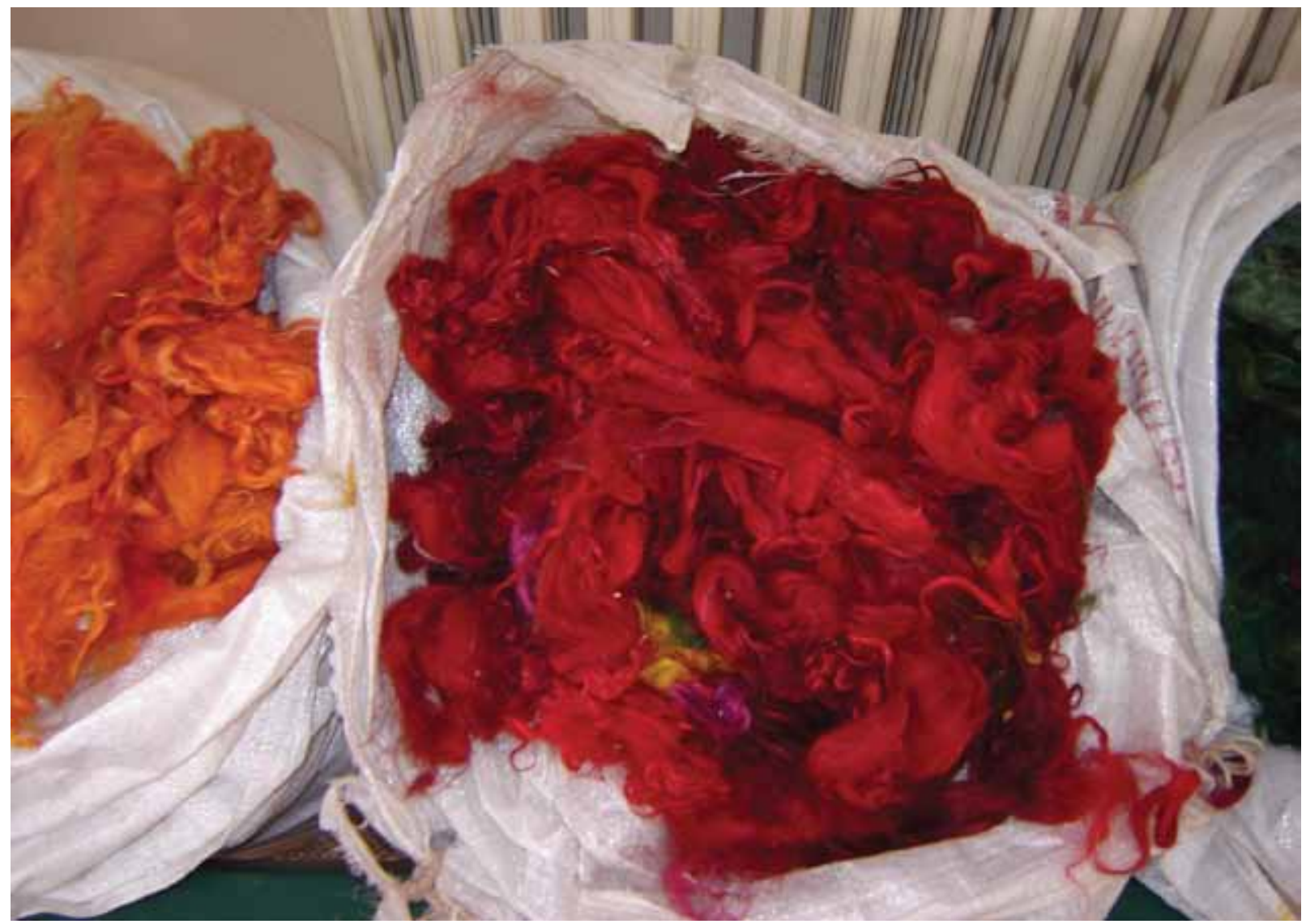

Foto 7. Hammaddenin depoda muhafaza edilişi.

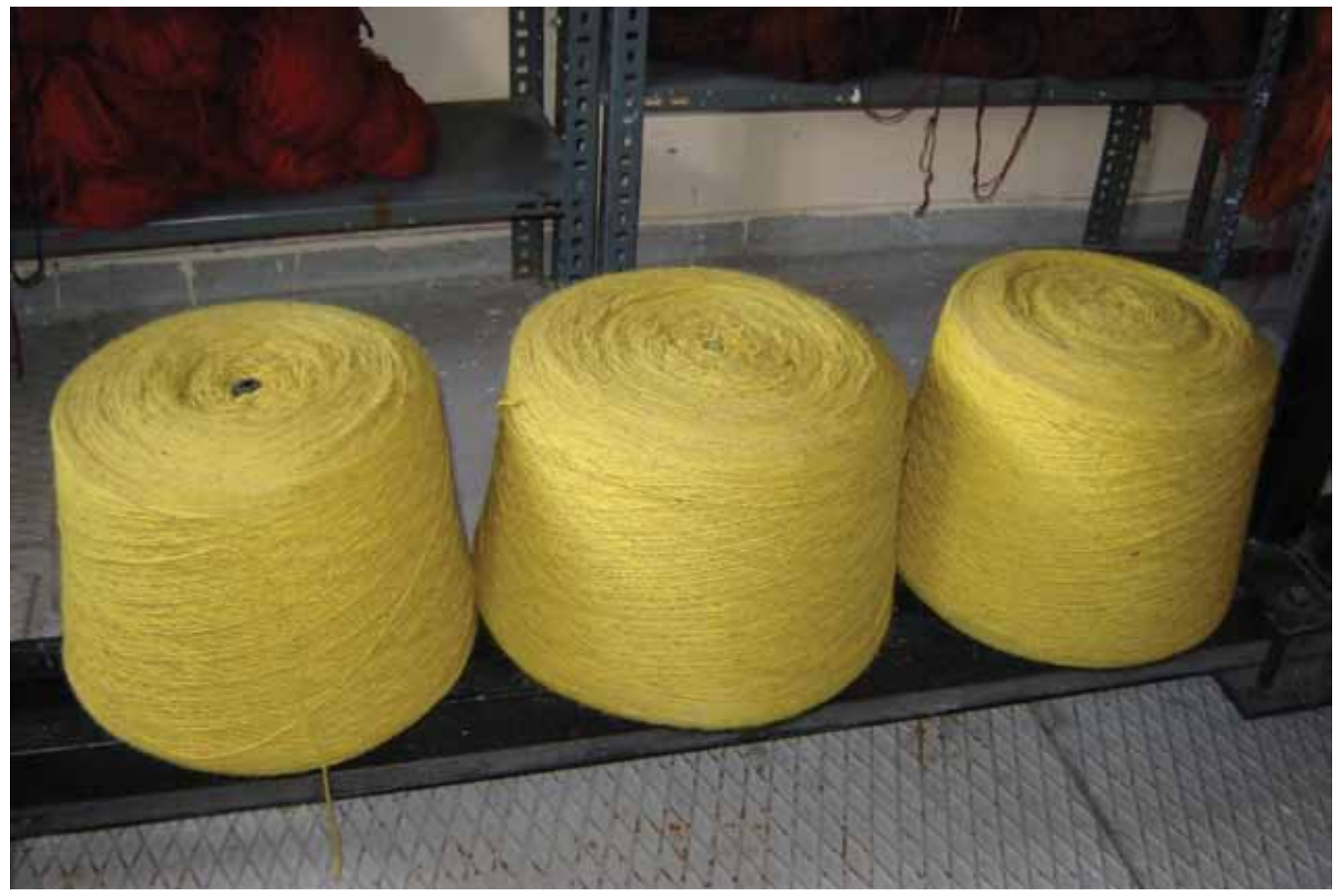

Foto 8. İpliğin depoda muhafaza edilişi 


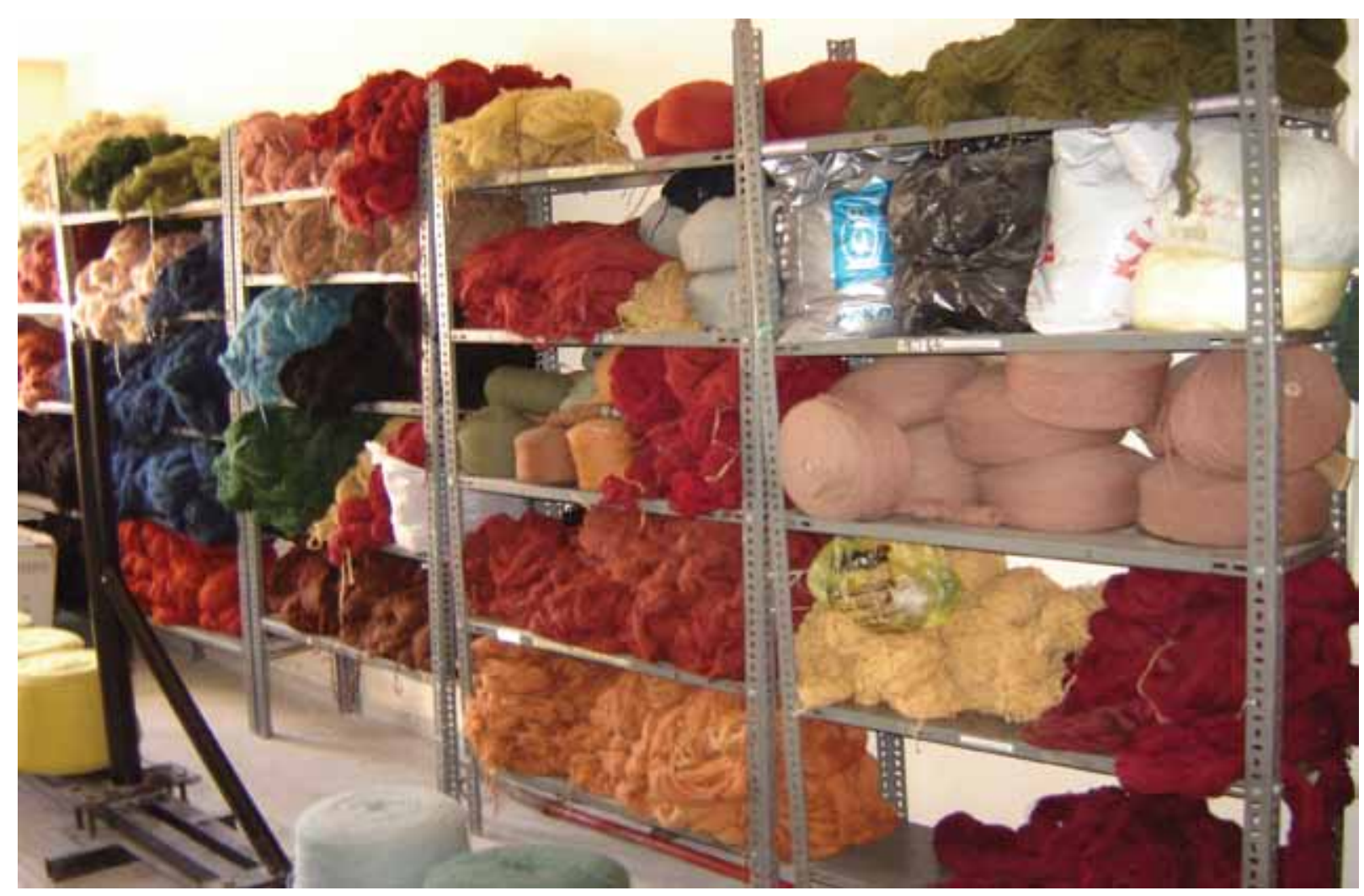

Foto 9. Deponun genel görünüşü.

uzunluklarının (tahta arası) ölçümü yapılırken metre ve mezür kullanılmıştır. Katalog kısmında yer alan örnekler ile ilgili bilgilerde sözlü kaynaklar dikkate alınmıştır.

Araştırmada 1950-2010 yılları arasında dokunmuş olan örnekler incelenmiş olup, bu örnekler kompozisyon, renk, kullanılan malzeme vb. özellikler bakımından değerlendirilmiştir. Yörede bulunan tülü dokumaları birbirini tekrar eder biçimde benzerlik gösterdiğinden bu sınırlı çalışmada katalog, karakteristik özellik taşıyan tek bir örnekle temsil edilmiş ve 6 örnek incelenmiştir. Ayrıca tülü dokumalarının bugünkü üretim koşulları yerinde incelenip, ürünlerin pazarlanması konusunda bilgi verilmeye çalışılarak önerilerde bulunulacaktır.

\section{Araştırma Bulguları}

Tülü dokumaları, genellikle yer yaygısı olarak kullanılmaktadır. Kış aylarında soğuktan korunmak amacıyla ya da dekoratif amaçlarla, duvara asılı olarak kullanımı da oldukça yaygındır. Bunun dışında, evlerin veya odaların giriş kısmında paspas olarak kullanılır. Yörede bulunan bir otelde, resepsiyondaki salonda tülü kullanıldığı görülmüştür. Tülünün ortama yöresel bir özellik kazandırmak amacıyla da kullanıldığı düşünülmektedir (Foto 12).

\section{1. Kullanılan Hammadde}

Tülü yapımında, yün ve tiftik yöre halkının kullandığı en önemli hammaddelerdir. Atkı ve çözgü ipi olarak yün, ilme ipi olarak ise daha kıvrımlı ve dökümlü durduğu için tiftik kullanılmaktadır. (Foto 7-8-9)

Çözgü için, Milas tipi olarak bilinen iki kat yün iplik, atkı ve düz (bezayağı) dokuma için ise iki bükümlü yün iplik kullanılmakta, ilmeler için tiftik kullanıldığıı görülmektedir.

Tiftik, post ve filik halinde satılmaktadır. Yörede, filik halinde satılan tiftik tercih edilip, tarama ve yıkama gibi bir işlem yapılmadan olduğu gibi kullanılmaktadır. Yün iplikler Isparta'dan, tiftik ise, Konya, Afyon ve Simav'dan temin edildiğgi öğrenilmiştir.

\section{2. Dokuma Tezgâhı}

Yörede Sarma tip metal tezgâh kullanılmaktadır. Sarma tip metal tezgâhların; dayanıklılık bakımından uzun ömürlü olmamaları, kuruluş, kullanım ve taşıma zorluklarının yanında ağacın özelliklerinden dolayı çarpılma, çatlama ve gönyelerinin bozulması gibi nedenler; dokuyucuları daha gelişmiş şekliyle sarma tip metal tezgâha yönlendirmiştir. İlçe merkezinde yapılan araştırmada, ıstar tipi denilen ilkel ahşap tezgâhlara rastlanmamıştır. Ancak köylerde bazı evlerde bu tip tezgâh kullanıldığı da bilinmektedir. (Foto 10).

Çözgü Aparatı: Sarma tip tezgâhlarda, çözgü çözülmesine yarayan, yapılacak dokumanın boyuna göre çözgü ipliklerinin ayarlanabildiği metalden yapılmış alete denir. Ray şeklinde zemine paralel bir köşebent demirin üzerine biri sabit, diğeri seyyar iki 


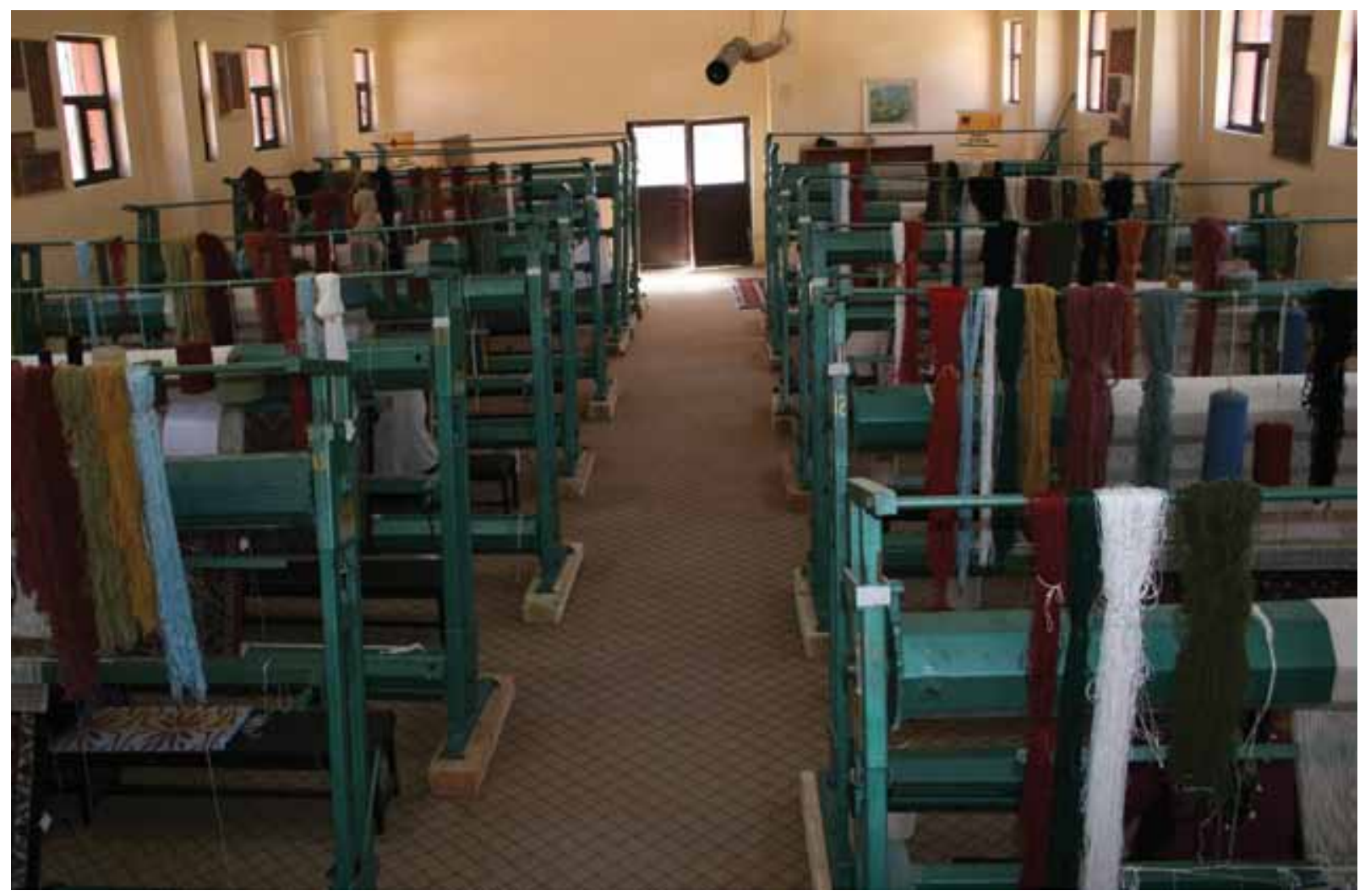

Foto 10. Tezgah

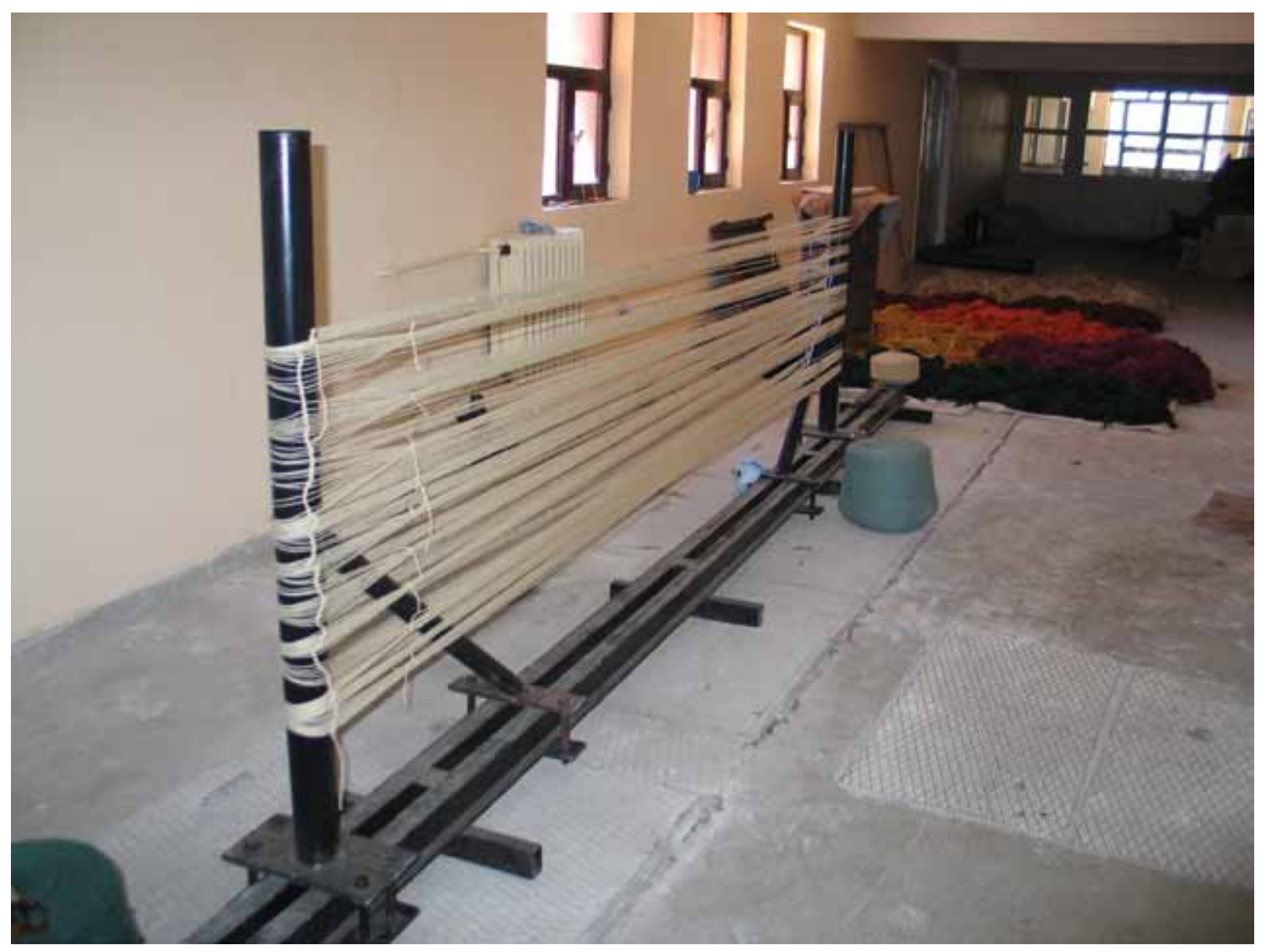


adet yuvarlak çubuğun dik olarak yerleştirilmesinden oluşmuştur (Foto 11).

Sarma tip tezgâhlarda çözgü aparatı kullanılarak çözgünün hazırlandığı ve tezgâha aktarılarak dokuma işlemine geçildiği saptanmıştır.

Yapılacak dokumanın ebadına göre saçak ve çözgü uzunluğu hesaplanarak aparat boyu buna göre ayarlanır.

Sabit olan bu çubuğa çözgü ipinin bir ucu bağlanır.

İki çubuk arasında, hep aynı yönde " 8 " yapacak şekilde çapraz olarak istenilen tel sayısı kadar çözgü çözülür.

Çözgülerin aynı gerginlikte olmasına dikkat edilir.

Çözgü ipliği sonunda yine sabit olan demir çubukta bitirilir.

Çözgünün her iki tarafına zincir çiti örülür.

Çözgünün ortasında oluşan çaprazlığın her iki tarafına kalın bir ip takılarak, düğüm atılır. Böylece oluşan çaprazlık bozulmadan çözgülerin tezgâha aktarılması sağlanmış olur.

Kirkit: Yörede metalden yapılmış kirkitlerin kullanıldı ̆̆ına rastlanmıştır.

\section{Çözgü Aparatında Hazırlanan Çözgüleri Tezgâha} Aktarma:

Aparattan çıkarılan çözgüler demir çubuklara aktarılır.

Çözgü tellerinin birbirine karışmamasına dikkat ederek, öncelikle üst levente gelecek olan demir çubuk, üst leventteki yuvasına sabitlenir.

Karışık teller el yardımıyla düzeltilerek çözgü alt levente sarılır. Sonra çözgüler üst levente sarılır. Çözgüler yerlerine oturup gerginlikleri eşitleninceye kadar bu işlem tekrarlanır ve sonunda varangelen takılır.

Çözgü tezgaha aktarıldıktan ve varangelen takıldıktan sonra, ağızlık örgüsü yapılır. Ağızlık ipinin uçları gergin bir şekilde yan taraflara bağlanır. Her sırada varangelen aşağı yukarı hareket ettirilir. Ağızlık örgüsü 3, 5 veya 7 sıra olarak yapılır.

Ağızlık örgüsü tamamlandıktan sonra çiti örgüsü olarak bilinen zincir örgüsü yapılır. Öncelikle çözgü için kullanılan ipten küçük bir yumak hazırlanır. Yumağın ucu sağ taraftaki bir çift çözgü teline bağlanır. Daha sonra çözgü iplikleri çift, çift alınarak zincir örgüsü tamamlanır.

Dokumanın başlangıcında çiti örgüsünden sonra, bitiminde ise çiti örgüsünden önce bezayağı tekniği ile toprakçalık olarak bilinen kilim örgüsü yapılır ve dokumaya başlanır.

Tülü dokumalarında havların uçları kesilmeden olduğu gibi bırakıldığı için, bıçak ve makas kullanılmaz. Kullanılan diğer araçlar, halı dokumada kullanılanlarla benzerlik göstermektedir.

\section{3. Kullanılan Teknik}

Tülü dokumalarında, yörede tahta arası diye tabir edilen havlar arasındaki kısımlar düz dokuma tekniği (bezayağı) kullanılarak, havlı kısımlar ise Gördes düğüm tekniği kullanılarak dokunmuştur.

Eski örneklerde düz dokuma kısımlarında cicim tekniği kullanılarak motif oluşturulmuş motiflere rastlanmış, bu motiflerin dokumanın tamamına düzensiz aralıklarla yerleştirildiği görülmüştür.

Düz dokuma tekniği (bezayağı) ile dokunan kısımların genişliği, hav için kullanılan yün veya tiftiğin uzunluğuna bağlı olarak 5-10 cm arasında olabilmektedir. Araştırma yapılan yörede, bu uzunluğun genellikle 7-9 cm. arasında değişkenlik gösterdiği tespit edilmiştir.

Yörede tülü dokumaya, öncelikle düz dokuma tekniği ile $1.5 \mathrm{~cm}$. genişliğindeki sıra dokunarak başlanır. Bunun üzerine, Gördes düğüm tekniği kullanılarak, bir sıra havlı dokuma yapılır. Düğümler halıdaki gibi iki çözgü üzerine bağlanır. Bir sıra tamamlandıktan sonra üzerinden atkı ipliği geçirilerek sıkıştırılır. Yün ve tiftiğin uzunluğuna göre $5-10 \mathrm{~cm}$. arasında düz dokuma yapıldıktan sonra, tekrar bir sıra havlı dokuma yapılır. Kenar örgüsü halı dokumada olduğu gibidir. Bu işlemler tekrarlanarak dokuma tamamlanır.

\section{4. Desen Motif ve Renk Özellikleri}

Tülü dokumada desen ve motifler, uçları serbest bırakılan havlar ile sağlanmaktadır. 5-10 sırada bir dokunan bu havlı kısımlarla desen oluşturmak oldukça zahmetli bir iştir. Bu nedenden dolayı tülü dokumaları, halı veya kilim dokumalarıyla kıyaslandığında, desen ve motif açısından çok fazla zenginlik gösteremez.

Eski örneklerde, havlar arasındaki düz dokuma k1sımlarında cicim tekniği kullanılarak pıtrak, koçboynuzu ve çengel motifleriyle süslemeler yapıldığı görülmüştür. Ancak günümüzde benzer örneklere sıklıkla rastlanmamaktadır.

Tülü dokumalarda kullanılan renklere bakıldığında, siyah ve beyaz tonların tiftiğin doğal renginden elde edildiği, diğer renklerin ise hammadde boyanarak sağlandığı görülmektedir. Renkler elde edilirken günümüzde kimyasal toz boyalar kullanılmakla birlikte 50-60 yıllık örneklerin doğal boyalarla renklendirildiği görülmektedir. Boyama, dokuyucular tarafından atölye ortamında yapilmaktadır.

Örneklere bakıldığında siyah, beyaz, turuncu, yeşil, kırmızı ve mavi en çok tercih edilen renkler olarak karşımıza çıkmaktadır. Renklendirme tamamen dokuyucunun isteğine göre ve eski dokumalar örnek alınarak belirlenmekte, bu tercihlerde canlı renkler önemli bir yer tutmaktadır. 


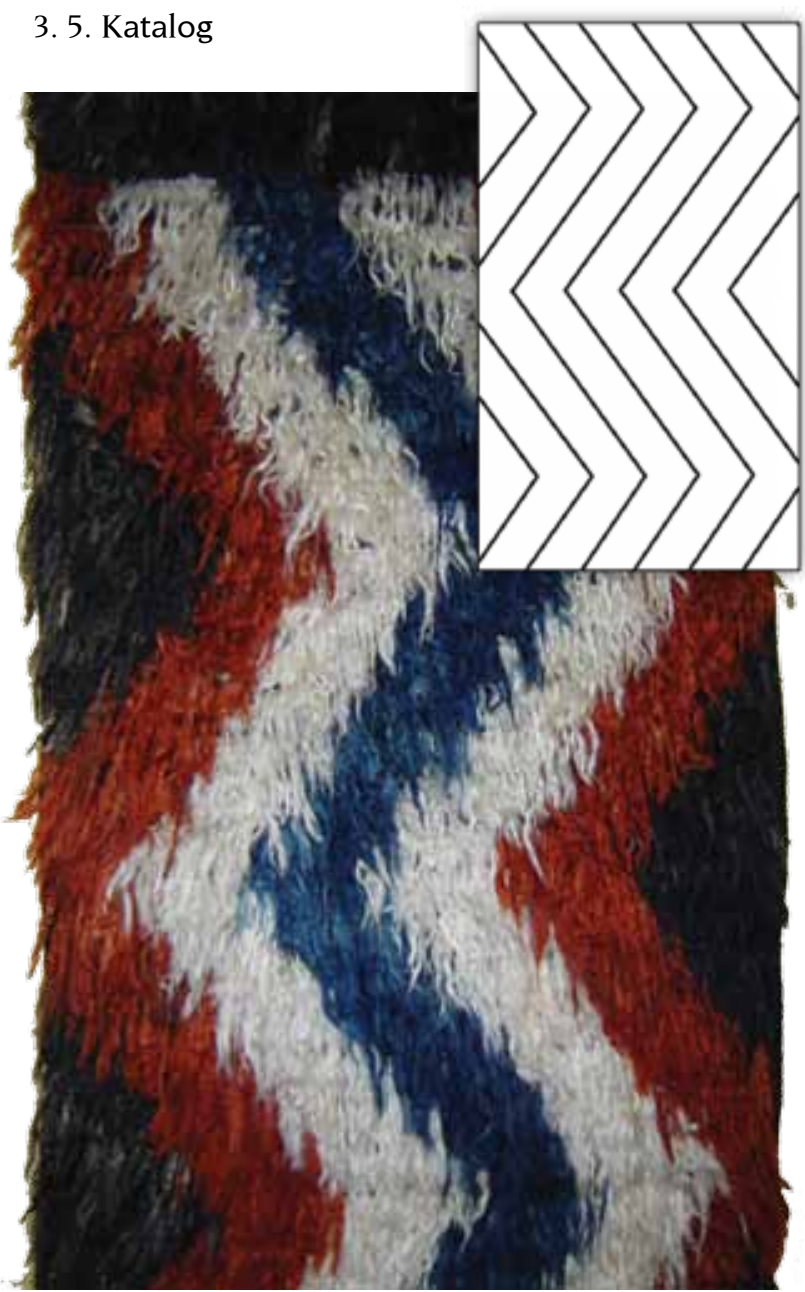

Foto 1. Örnek 1, Şekil 1. Örnek l'in desen şeması

\section{1. Örnek}

2004 yılında dokunan tülü onarım görmemiştir. Atkı, çözgü ipliği yün, ilme olarak tiftik kullanılmıştır. Boyutları; en: $100 \mathrm{~cm}$. boy: $200 \mathrm{~cm}$.dir. Hav yüksekliği (filik uzunluğu); $17 \mathrm{~cm}$. havlar arasındaki kilim örgü (tahta arası): $7 \mathrm{~cm}$. ve saçak uzunluğu $12 \mathrm{~cm}$. olarak ölçülmüştür. Kullanılan renklere bakıldığında kırmızı, beyaz, mavi, siyah göze çarpmaktadır. Tülünün düz dokuma zemini siyah renktedir. Kompozisyon; kırmızı, beyaz, siyah ve mavi renklerde beş adet zikzak bordürler biçiminde düzenlenmiştir. Kısa kenarlar, Kastamonu çarşaf düğümü tekniği ile temizlenmiştir. (Foto 1.) - (Şekil 1.)

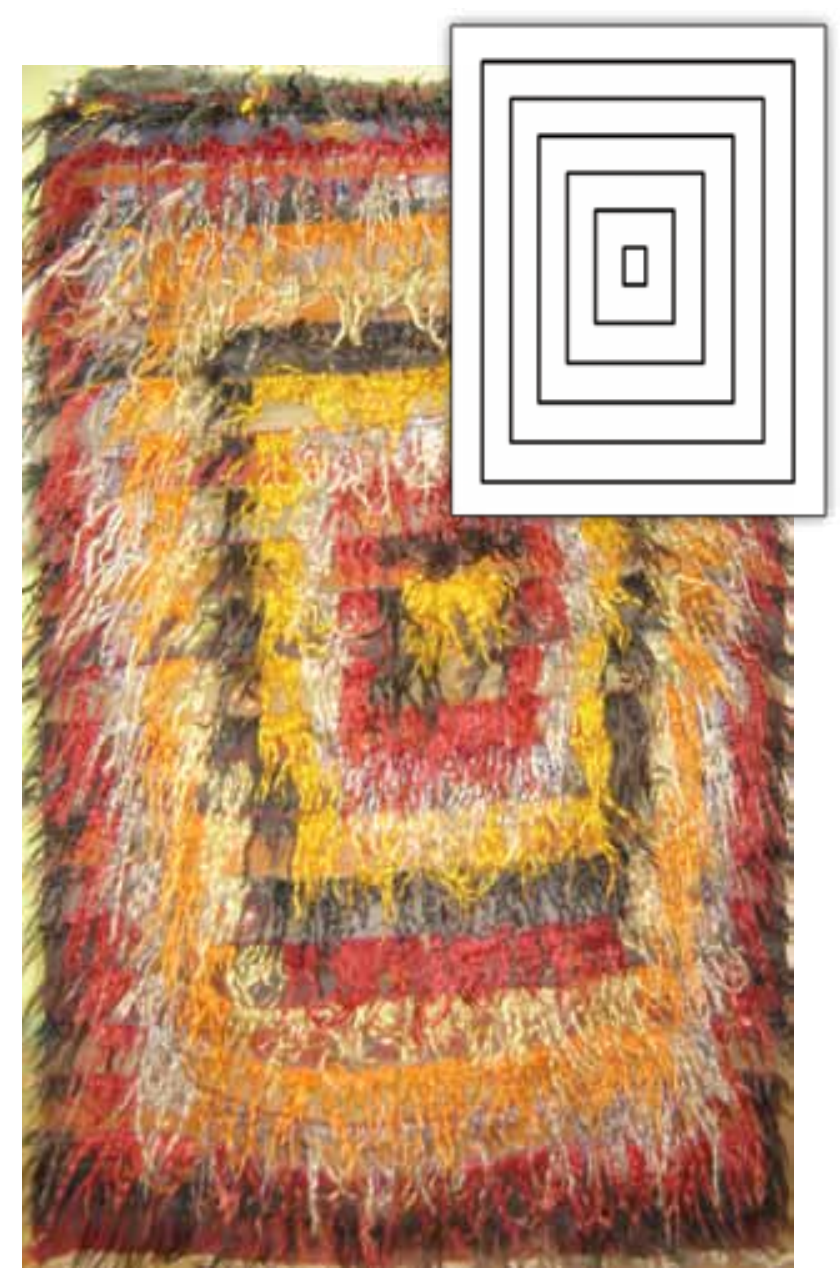

Foto 2. Örnek 2, Şekil 2. Örnek 2'nin desen şeması

\section{2. Örnek}

Dokuyucusu bilinmeyen bu örnek 1950 yılına tarihlendirilmektedir ve onarım görmemiştir. Atkı, çözgü ipliği yün, ilme olarak tiftik kullanılmıştır. Boyutları; en: $135 \mathrm{~cm}$. boy: $180 \mathrm{~cm}$. dir. Hav yüksekliği (filik uzunluğu); $17 \mathrm{~cm}$. havlar arasındaki kilim örgü (tahta arası): $7 \mathrm{~cm}$. ve saçak uzunluğu $12 \mathrm{~cm}$. olarak ölçülmüştür. Kullanılan renklere bakıldığında siyah, beyaz, sarı, açık sarı, turuncu, kırmızı, mavi ve küf yeşili göze çarpmaktadır. Tülünün zemini dikdörtgen biçiminde birbirinin içine yerleştirilmiş farklı renklerdeki on adet ince bordürden oluşmaktadır. Dış bordür siyah renkte olup, içeriye doğru kırmızı, açık mavi, turuncu, açık sarı, siyah, sarı, açık mavi, kırmızı, siyah renklerdeki bordürler bulunmakla birlikte orta kısım sarı renk ile doldurulmuştur. Düz dokumasında, farklı renklerle oluşturulan şeritlerin içine, belirli bir düzene bağlı kalınmadan koçboynuzu, pitrak ve çengel motifleri yerleştirilmiştir. Bu şeritler oluşturulurken, sarı, kırmızı, mavi, siyah, beyaz ve küf yeşili renkleri kullanılmıştır. Kısa kenarlar, saçak bağlanarak temizlenmiştir. (Foto 2.) - (Şekil 2.) 


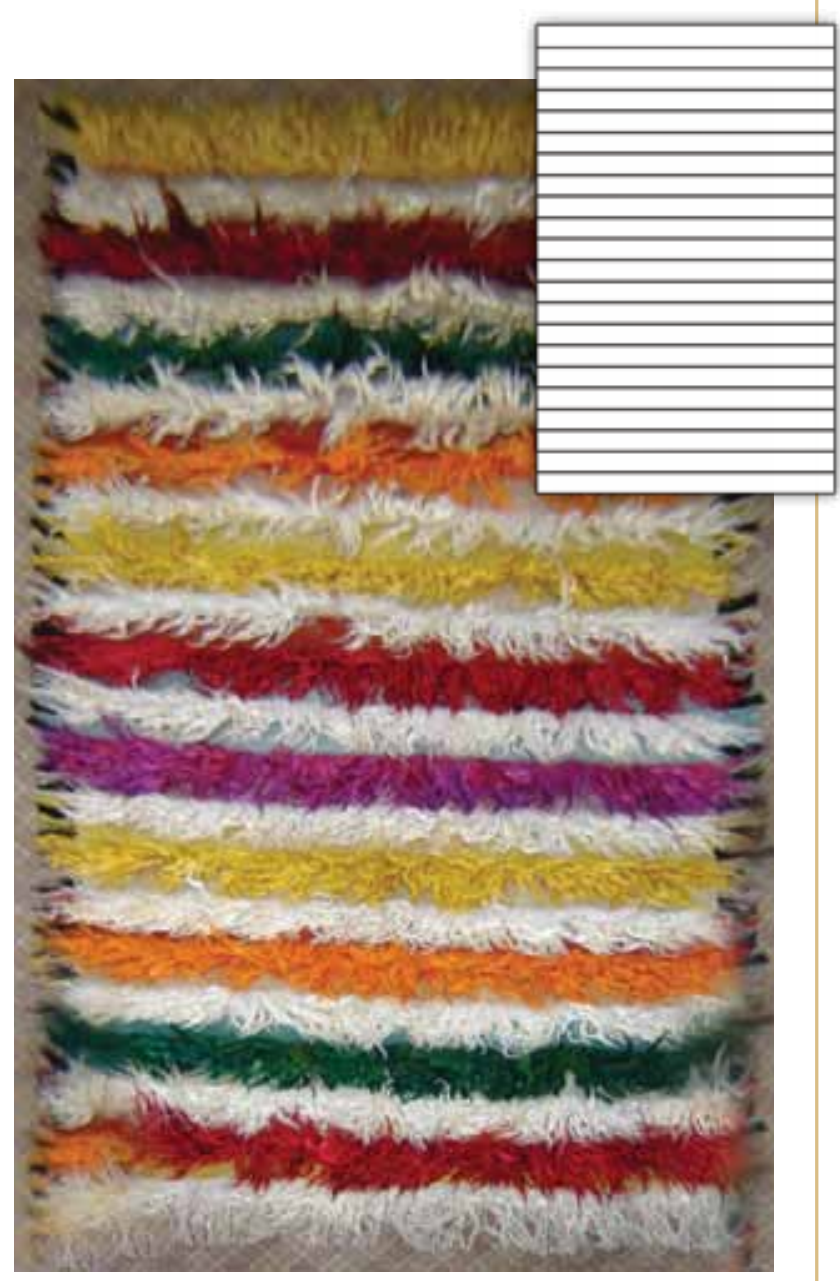

Foto 3. Örnek 3, Şekil 3. Örnek 3'ün desen şeması

\section{3. Örnek}

Eğitim atölyesinde Döne Kaya'nın dokuduğu örnekte atkı, çözgü ipliği yün, ilme olarak tiftik kullanılmıştır. Boyutları; en: 104 cm. boy: $200 \mathrm{~cm}$.dir. Hav yüksekliği (filik uzunluğu); $13 \mathrm{~cm}$. havlar arasındaki kilim örgü (tahta arası): $9 \mathrm{~cm}$. ve saçak uzunluğu $12 \mathrm{~cm}$. olarak ölçülmüştür. Kullanılan renklere bakıldığında beyaz, kırmızı, yeşil, turuncu, sarı, mor ve siyah göze çarpmaktadır. Tülünün zemini enine düz çizgiler oluşturacak şekilde, bir beyaz bir renkli şerit tekrarından oluşmaktadır. Renkli şeritler; Kırmızı, yeşil, turuncu, sarı, mor, kırmızı, sarı, turuncu, yeşil, kırmızı, sarı şeklinde sıralanmıştır. Düz dokuması da sarı, kırmızı ve yeşil renk şeritlerin her birinin arasına beyaz şerit dokuması yapılarak tekrar etmektedir. Tülünün uzun kenarlarına siyah, mavi ve kırmızı renklerde püsküller yapılmıştır. Kısa ve uzun kenarlar, saçak bükülerek temizlenmiştir. (Foto 3.) - (Şekil 3.)

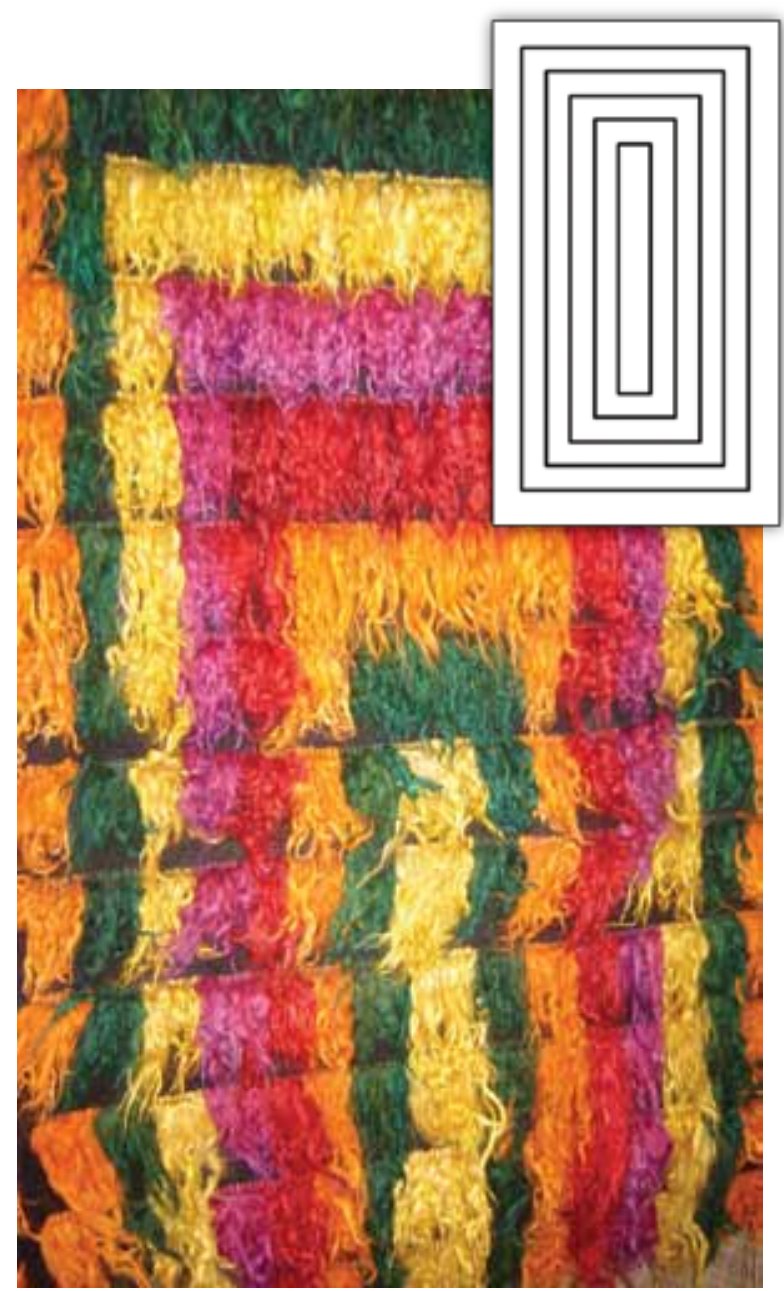

Foto 4. Örnek 4, Şekil 4. Örnek 4'ün desen şeması

\section{4. Örnek}

Eğitim atölyesinde Emine Hançerli'nin dokuduğu örnekte atkı, çözgü ipliği yün, ilme olarak tiftik kullanılmıştır. Boyutları; en:92 cm. boy: 200 cm.dir. Hav yüksekliği (filik uzunluğu); $14 \mathrm{~cm}$. havlar arasındaki kilim örgü (tahta arası): $9 \mathrm{~cm}$. ve saçak uzunluğu $14 \mathrm{~cm}$. olarak ölçülmüştür. Kullanılan renklere bakıldığında turuncu, yeşil, sarı, mor, kırmızı ve siyah göze çarpmaktadır. Tülünün zemini iç içe geçmiş farklı renkte, dikdörtgen biçimindeki yedi adet ince bordürden oluşmaktadır. Dış bordür turuncu renkte olup, diğer bordürler içeriye doğru; yeşil, sarı, mor, kırmızı, turuncu ve yeşil olarak yerleştirilmiştir. İçeride kalan bordürün ortası sarı renkle doldurulmuştur. Düz dokuması siyah renkle dokunmuştur. (Foto 4.) - (Şekil 4.) 


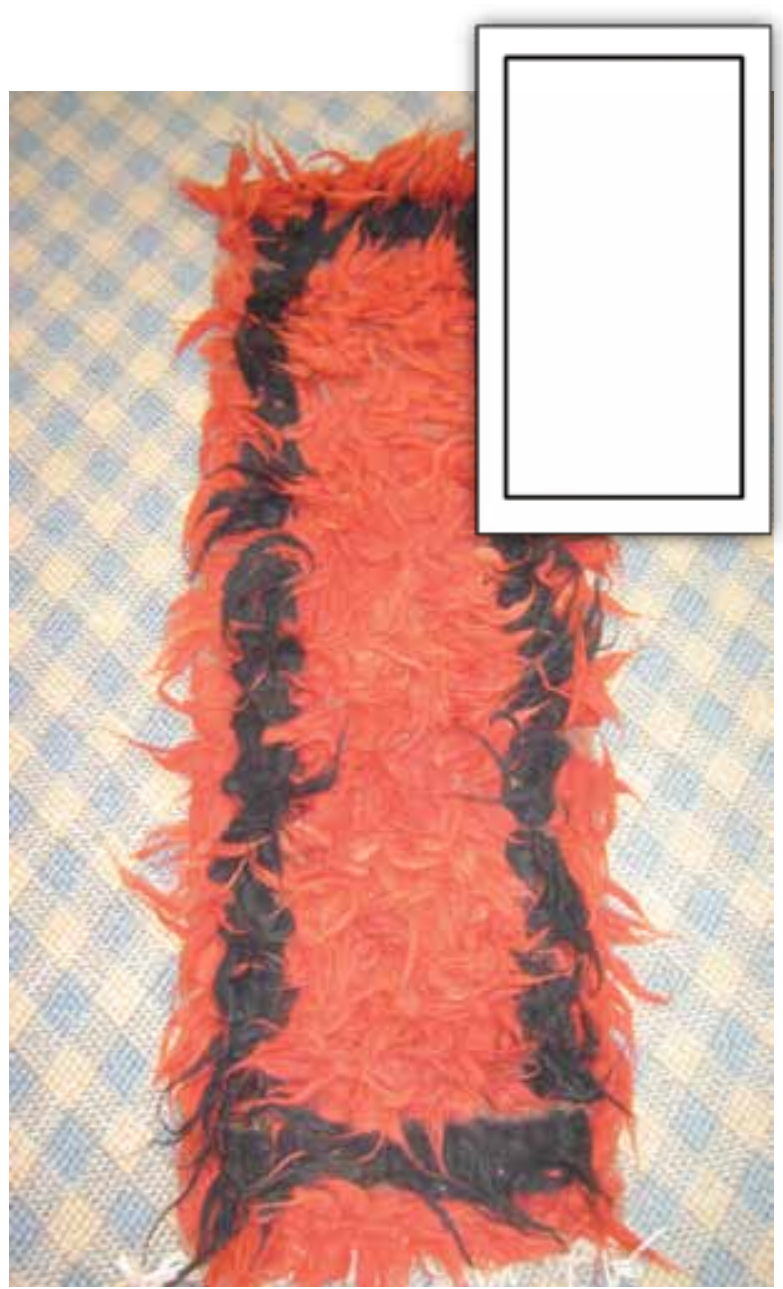

Foto 5. Örnek 5, Şekil 5. Örnek 5'in desen şeması

\section{5. Örnek}

2006 yılında dokunan bu örnek onarım görmemiştir. Atkı ve çözgü ipliği olarak yün, ilme olarak tiftik ve yün karışımı kullanıldığı görülmüştür. Boyutları; en:37 cm. boy: $97 \mathrm{~cm}$. dir. Hav yüksekliği (filik uzunluğu); $13 \mathrm{~cm}$. havlar arasındaki kilim örgü (tahta arası): $3 \mathrm{~cm}$. ve saçak uzunluğu $7 \mathrm{~cm}$. olarak ölçülmüştür. Kullanılan renklere bakıldığında kırmızı ve siyah göze çarpmaktadır. Tülünün zemini kırmızı renkte olup, siyah renkte bir adet ince bordürle sınırlandırılmıştır. Düz dokuması, kırmızı renkte dokunmuştur. Kısa kenarlar, saçak bükülerek temizlenmiştir. (Foto 5.) - (Şekil 5.)

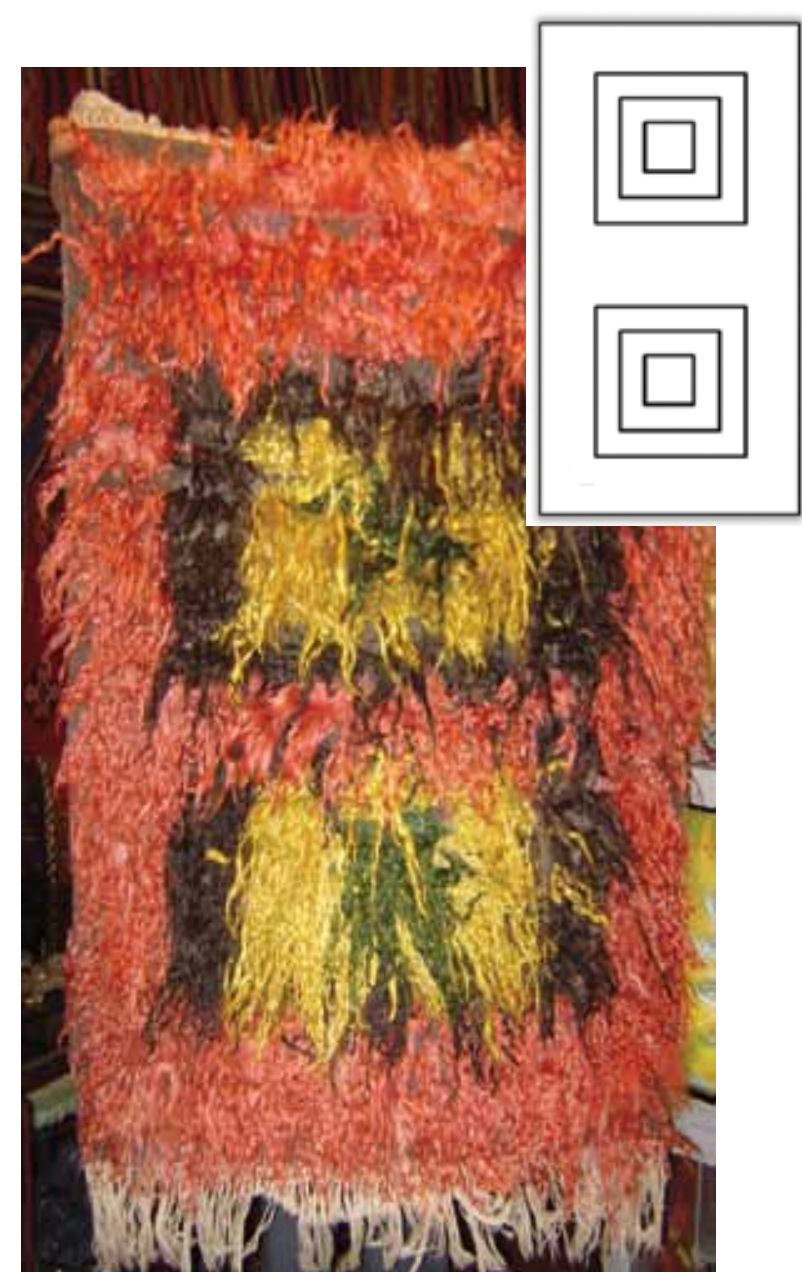

Foto 6. Örnek 6, Şekil 6. Örnek 6'nın desen şeması

\section{6. Örnek}

2004 yılında dokunan tülü onarım görmemiştir. Dokuyan kişisi bilinmeyen örnekte atkı ve çözgü ipliği olarak yün, ilme olarak tiftik kullanıldığı görülmüştür. Boyutları; en:95 cm. boy: $107 \mathrm{~cm}$.dir. Hav yüksekliği (filik uzunluğu); $17 \mathrm{~cm}$. havlar arasındaki kilim örgü (tahta arası): $7 \mathrm{~cm}$. ve saçak uzunluğu $12 \mathrm{~cm}$. olarak ölçülmüştür. Kullanılan renklere bakıldığında kırmızı, siyah, sarı ve yeşil göze çarpmaktadır. Tülü zemini kırmızı renkte, düz dokuması ise siyah renkte dokunmuştur. İki adet iç içe geçmiş kare biçimi tekrarlamalı olarak zemine yerleştirilmiştir. Kare biçimindeki eşkenar dörtgenlerden diştakiler siyah, içeridekiler sarı renkte olup, orta kısımları yeşil renkle doldurulmuştur. Kısa kenarlar, saçak bağlanarak temizlenmiştir. (Foto 6.) - (Şekil 6.) 


\section{Değerlendirme ve Sonuç}

Araştırmada altı örnek incelenmiş olup, bu örneklerin tamamında teknik özelliklerinin aynı, renk ve kompozisyon özelliklerinin farklı olduğu saptanmıştır. Bu durum yörede desen açısından bir etkileşim olduğunu göstermektedir.

Hammadde açısından bakıldı ̆̆ında incelenen beş örneğin atkı ve çözgüleri yün, ilmeleri tiftik olarak, diğer bir örnekte ise, atkı ve çözgüleri yün, ilmeleri yün ve tiftik karışımı olarak dokunduğu görülmektedir.

Yıldızeli ilçe merkezinde, günümüzde evlerde dokuma işi yapılmamaktadır. Dokuma yapmak veya öğrenmek isteyenler, Eğitim Atölyesi'ni tercih etmektedirler.

Alınan siparişlerde, müşterilerin renk ve desen tercihi belirtmediği, eserin kompozisyonunu tamamen dokuyucunun belirlediği saptanmıştır. Bu noktada elli - altmış yıllık en eski örneklerin kompozisyon özelliklerinin tekrarlandığı görülmüştür. Dolayısıyla eski eserlerin günümüze taşınması sağlanmıştır.

İncelenen örneklerde sıcak renklerin tercih edildiği görülmüştür. Örneklere bakıldığında siyah, beyaz, turuncu, yeşil, kırmızı ve mavi en çok tercih edilen renkler olarak karşımıza çıkmaktadır. Dokumalarında, doğal boya yerine kimyasal boyaların tercih edildiği saptanmıştır.

Tülü dokumalarının, yörede genel olarak duvar örtüsü ve yer yaygısı olarak kullanıldığı tespit edilmiştir. Sivas'ın çeşitli yörelerinde, yatak örtüsü, beşikörtüsü ve seccade gibi kullanım alanları da bulunmaktadır. Karapınar yöresinde genellikle minder olarak, Kayseri Pınarbaşı yaylalarında, develer için süs örtüsü olarak kullanılmaktadır. Mut yöresinde, sedir örtüsü ve minder olarak kullanımı yaygındır. ${ }^{8}$ Ayrıca, bazı yiyeceklerin sıcaktan etkilenmemeleri için üzerine tülü örtüldüğü ve bu işleme de "bastırık" adı verildiği çeşitli kaynaklarda yer almaktadır. ${ }^{9}$ Ancak, günümüzde tülü dokumaları daha çok dekoratif amaçlı olarak kullanılmaktadır.

Anadolu'da dokunan diğer örneklerle karşılaştırıldığında, kullanılan hammadde ve teknik açısından benzerlikler bulunmaktadır. Ancak renk, desen ve kompozisyon açısından benzer örnekler bulunmakla birlikte, farklılıklar görülmüştür. Yörede, en çok madalyonlu, kareli, enine çubuklu, zikzaklı, düz ve çerçeveli tülü örnekleri dokunmaktadır. Çeşitli yörelerde örnekleri bulunan, mihraplı, taraklı, figürlü ve bitkisel bezemeli tülülere bu yörede rastlanmamıştır.

İncelenen eski örneklerin düz dokuma kısımlarında cicim tekniği kullanılarak motif oluşturulmuş ve bu motifler dokumanın tamamına düzensiz aralıklarla yerleştirilmiştir. Doğu ve Orta Anadolu'daki bazı

8 N. Kırzıoğlu, Görgünay, Düğümlü Halının Öncüsü Geve/Tülü ve Benzeri Dokumalar, Türk Dünyası Araştırmaları Vakfı, İstanbul, 2000, s.56.

9 H. Durmuş, Dokuma Kursu Eğitim Kitabı, Sivas, 2007, s. 16. örneklerde ise, düğüm sıraları arasındaki düz dokumalar zili tekniği ile oluşturulmuştur. ${ }^{10} \mathrm{Bu}$ dokumalarda atkı ve çözgü ipi olarak yine yün kullanılmıştır.

İncelenen tülü dokumalarının ebatları; $37 \times 97 \mathrm{~cm}$. ile $115 \times 215 \mathrm{~cm}$. arasında değişiklik göstermektedir.

Dokumanın kültürünün korunması ve sonraki nesillere aktarılması açısından, bu işin eğitimini almış araştırmacılar tarafından doğru araştırmalar yapılmalıdır. Yapılan araştırmada bulunan eski örnekler kayıt altına alınarak korunmalı, dokunacak yeni örneklere rehberlik etmesi sağlanmalıdır.

Bilinçli girişimciler tarafından geleneksel örneklere uygun olarak, üretime yönelik çalışmalar yapılmalıdır. Devlet bu tür girişimleri desteklemelidir. Dokuma atölyeleri denetlenmeli, geleneksel yapıdan uzak olarak üretim yapan atölyelere gerekli uyarılar yapılmalıdır.

Ayrıca yörede geliştirilen ve uygulanan Avrupa Birliği projesi, farklı alanlarda da rehberlik eden bir faaliyet olarak değerlendirilmeli ve hem ülkemiz, hem de yöre halkı için fayda sağlayacak farklı projeler geliştirilmelidir.

\section{Kaynaklar}

Acar - Balpınar, Belkıs (1982), Kilim, Cicim, Zili, Sumak Türk Düz Dokuma Yaygıları, İstanbul: Eren Yayınları.

Aslanapa, Oktay (2005), Türk Halı Sanatının Bin Yilı, İstanbul: İnkılap Yayınevi.

Aytaç, Ahmet (1999), Geleneksel Türk El Dokumaciliğı Sanatı, Konya.

Aytaç, Çetin (1982), El Dokumacılı̆̆ı, Ankara: Milli Eğitim Basimevi.

Aytaç, Çetin (1997), El Dokumacilı̆̆ Temel Ders Kitabı, İstanbul: Milli Eğitim Basımevi.

Aytaç, Çetin (2001), Halı Deseni Tasarımı, Ankara: Ostim Mesleki Eğitim Merkezi.

Barışta, H. Örcün (27-31 Mayıs, 1996). “19-20. Yüzyıl İç Anadolu ve Orta Akdeniz Bölgesi Türk Kirkitli Dokumaları Üzerine" Türk Soylu Halklarının Halı, Kilim, Cicim Sanatı Uluslararası Bilgi Şöleni Bildirileri, Kayseri: Atatürk Kültür Merkezi Başkanlığı Yayınları, s. 39-56

Deniz, Bekir (2000), Türk Dünyasında Halı ve Düz Dokuma Yaygllar, Ankara: Atatürk Kültür Merkezi Yayınları.

Denizli, Hikmet (2002), Sivas Tarihi ve Anttları, Sivas: Özbelsan A.Ş. Kültür Yayınları.

Durmuş, Hüseyin (2007), Dokuma Kursu Eğitim Kitabı, Sivas.

Erdmann, Kurt (1960), 15.Asir Türk Halısl, İstanbul: İstanbul Üniversitesi Edebiyat Fakültesi Yayınları, Maarif Basimevi.

Hidayetoğlu, H. Melek (1999), Karapınar Tülü Dokumaları, Konya, Selçuk Üniversitesi, Sosyal Bilimler Enstitüsü, Basılmamış Yüksek Lisans Tezi.

10 B. Deniz, Türk Dünyasinda Halı ve Düz Dokuma Yaygılar, Atatürk Kültür Merkezi Yayınları, Ankara, 2000, s.126. 
Kırzıoğlu, Görgünay, N. (27-31 Mayıs, 1996), "Altaylarda Pazırık Kurganı'ndan Çıkan Motiflerin Anadolu ve Türk Cumhuriyetleri'nde Yaşayan İzlerinden Bazı Örnekler", Türk Soylu Halklarının Halı, Kilim, Cicim Sanatı Uluslararası Bilgi Şöleni Bildirileri, Kayseri: Atatürk Kültür Merkezi Başkanlığı Yayınları. s. 137-150.

Kırzıoğlu, Görgünay, N. (2000), Düğümlü Halının Öncüsü Geve/ Tülü ve Benzeri Dokumalar, İstanbul: Türk Dünyası Araştırmaları Vakfı.

Korkusuz, (Yüksel), Süheyla (1971), Nakış Temel Bilgileri Tekniği Uygulamaları ve Örnekleri, Ankara.

Mahiroğulları, M., Ahmet (2003), Ilk Çağlardan Günümüze Sivas Ili, Sivas.

Megep, (2008), El Sanatları Teknolojisi, Tülü Dokuma, Mesleki Eğitim ve Öğretim Sisteminin Güçlendirilmesi Projesi, Ankara: Milli Eğitim Bakanlığı.

Öktem Tülin, Atav Rıza (Nisan-Haziran 2006), Tiftik (Ankara Keçisi) Liflerinin Yapısal Özellikleri, Tekstil ve Konfeksiyon, 2. Ege Üniversitesi Tekstil ve Konfeksiyon Araştırma Uygulama Merkezi Yayını.

Özen, Kutlu (2008), Sivas Yöresi Geleneksel El Sanatları, İstanbul: Kitabevi Yayınevi.
Özkan, N. Ayşe (1999), Adıyaman ve Köylerinde Dokunan Tülülerin Genel Özellikleri, Selçuk Üniversitesi Sosyal Bilimler Enstitüsü Dergisi, S. 4.

Sivas Ill Yilliğı (2002), Sivas Valiliğii, Sivas.

Yetkin, Şerare (1991), Türk Halı Sanatı, Ankara: Türkiye İş Bankası Kültür Yayınları.

\section{Kaynak Kişiler}

- Hüseyin Durmuş (1. Örnek - 2. Örnek - 6. Örnek) Adres: Akdeğirmen mah. 10.sk. Sena Apt. No:5/1 Sivas.

Tarih: 16.03.2010

- Döne Karakaya (3.Örnek)

Adres: Eğitim Atölyesi - Yıldızeli / Sivas

Tarih: 17.03.2010

- Emine Hançerli (4.Örnek)

Adres: Eğitim Atölyesi - Yıldızeli / Sivas

Tarih: 17.03.2010

- Emine Tonus (5.Örnek)

Adres: Cumhuriyet Üniversitesi, SMYO, Sivas.

Tarih: 17.03.2010 